\title{
Silicon Improves Maize Photosynthesis in Saline-Alkaline Soils
}

\author{
Zhiming Xie, ${ }^{1,2}$ Ri Song, ${ }^{3}$ Hongbo Shao, ${ }^{4}$ Fengbin Song, ${ }^{2}$ Hongwen Xu, ${ }^{5}$ and Yan $\mathrm{Lu}^{5}$ \\ ${ }^{1}$ College of Life Sciences, Baicheng Normal University, Baicheng 137000, China \\ ${ }^{2}$ Northeast Institute of Geography and Agroecology, Chinese Academy of Sciences, Changchun 130102, China \\ ${ }^{3}$ College of Agronomy, Jilin Agricultural University, Changchun 130118, China \\ ${ }^{4}$ Key Laboratory of Coastal Biology \& Bioresources Utilization, Yantai Institute of Coastal Zone Research, \\ Chinese Academy of Sciences (CAS), Yantai 264003, China \\ ${ }^{5}$ School of Urban and Environmental Science, Huaiyin Normal University, Huaian 223300, China
}

Correspondence should be addressed to Hongbo Shao; shaohongbochu@126.com and Fengbin Song; fb_song@163.com

Received 10 June 2014; Accepted 26 June 2014

Academic Editor: Marian Brestic

Copyright (C) 2015 Zhiming Xie et al. This is an open access article distributed under the Creative Commons Attribution License, which permits unrestricted use, distribution, and reproduction in any medium, provided the original work is properly cited.

\begin{abstract}
The research aimed to determine the effects of $\mathrm{Si}$ application on photosynthetic characteristics of maize on saline-alkaline soil, including photosynthetic rate $\left(P_{n}\right)$, stomatal conductance $\left(g_{s}\right)$, transpiration rate $(E)$, and intercellular $\mathrm{CO}_{2}$ concentration $\left(C_{i}\right)$ of maize in the field with five levels $\left(0,45,90,150\right.$, and $\left.225 \mathrm{~kg} \cdot \mathrm{ha}^{-1}\right)$ of Si supplying. Experimental results showed that the values of $P_{n}, g_{s}$, and $C_{i}$ of maize were significantly enhanced while the values of $E$ of maize were dramatically decreased by certain doses of silicon fertilizers, which meant that Si application with proper doses significantly increased photosynthetic efficiency of maize in different growth stages under stressing environment of saline-alkaline soil. The optimal dose of Si application in this experiment was $150 \mathrm{~kg} \cdot \mathrm{ha}^{-1} \mathrm{Si}$. It indicated that increase in maize photosynthesis under saline-alkaline stress took place by Si application with proper doses, which is helpful to improve growth and yield of maize.
\end{abstract}

\section{Introduction}

Salinity and sodicity toxicities are worldwide agricultural and ecoenvironmental problems; it is estimated that there is approximately 27 million hectares of salinised soils in China's coastal and inland areas [1]. The saline and sodic soils, among which about $23 \%$ of the cultivated lands are saline and $37 \%$ are sodic, cover about $10 \%$ of total arable lands worldwide [2]. This kind of soil is widespread in arid and semiarid regions of the world and causes severe environmental and agricultural problems [3]. Soil salinity and sodicity, which seriously affect the stages of germination, seedling growth and vigour, vegetative growth, flowering, and fruit set of crops [4], adversely affect crop production in different regions, especially in arid and semiarid regions of the world $[5,6]$.

Supplement silicon, which is much cheaper than other methods to minimize salinity and sodicity, such as reclamation, water, and drainage, is an alternative way for overcoming the negative effects of salinity and sodicity on the plant growth and yield [7]. The beneficial effect of silicon is more evident under stress conditions; this is because silicon is able to protect plants from multiple abiotic and biotic stresses [8]. Silicon can alleviate the adverse effects of salt stress on plants by increasing cell membrane integrity and stability through its ability to stimulate the plants' antioxidant system [9]. Silicon application can moderate the salinity and sodicity stress in plants and plays a multitude of roles in plant existence and crop performance, and silicon is deposited in leaves leading towards decreased transpiration and hence dilutes salts accumulated in saline environment [10]. In general, graminaceous plants accumulate much more silicon in their tissues than other species [11].

Maize (Zea mays L.) is reported as salt susceptible [12]. This study aimed to investigate the effects of silicon fertilizer, which was conducted in field tests, on photosynthetic characteristics of maize under the condition of saline-alkaline soil in Northeast China. 


\section{Materials and Methods}

2.1. Experimental Site and Soil Condition. During May to October, 2012, the field experiments were carried out in Agricultural Research Center in Gaoping Village, Baicheng City, Jilin Province, China $\left(45.38^{\circ} \mathrm{N}\right.$ latitude, $122.50^{\circ} \mathrm{E}$ longitude), on an saline-alkaline soil, where the climatic conditions are as follows: continental monsoon climate, lying in midtemperate zone, a mean annual temperature being $4.9^{\circ} \mathrm{C}$, the annual sunshine time being 2, 919.4 hours, an average frost-free period being 157 days, and the annual average precipitation being $399.9 \mathrm{~mm}$ with $88 \%$ distributed in May-September. The basic properties of the soil $(0-20 \mathrm{~cm})$, which is saline-alkaline soil, are that it contains organic matter $19.6 \mathrm{~g} \cdot \mathrm{kg}^{-1}$, available nitrogen 112.46 , available phosphorus $11.38 \mathrm{mg} \cdot \mathrm{kg}^{-1}$, available potassium $162.39 \mathrm{mg} \cdot \mathrm{kg}^{-1}$, available silicon $238.60 \mathrm{mg} \cdot \mathrm{kg}^{-1}$, ESP $11.36 \%$, EC $9.88 \mathrm{dS} \cdot \mathrm{m}^{-1}$, $\mathrm{K}^{+} 83.62 \mathrm{mg} \cdot \mathrm{kg}^{-1}, \mathrm{Na}^{+} 405.76 \mathrm{mg} \cdot \mathrm{kg}^{-1}, \mathrm{Ca}^{2+} 43.26 \mathrm{mg} \cdot \mathrm{kg}^{-1}$, $\mathrm{Mg}^{2+} 65.68 \mathrm{mg} \cdot \mathrm{kg}^{-1}, \mathrm{Cl}^{-} 69.18 \mathrm{mg} \cdot \mathrm{kg}^{-1}, \mathrm{HCO}_{3}{ }^{-} 896 \mathrm{mg} \cdot \mathrm{kg}^{-1}$, $\mathrm{SO}_{4}{ }^{2-} 40.75$, and $\mathrm{pH} 8.00$.

2.2. Experimental Design. The experiment was conducted in the form of randomized complete block design (RCBD) with three replications in a $5 \times 10 \mathrm{~m}^{2}$ net plot size. Maize (Zhengdan 958) was sown on May 6 with a density of 65000 plants $\cdot \mathrm{ha}^{-1}$. A uniform dose of basal fertilizer was applied to all experimental plots prior to seed sowing with $\mathrm{N} 200 \mathrm{~kg} \cdot \mathrm{ha}^{-1}$ as urea, $\mathrm{P}_{2} \mathrm{O}_{5} 100 \mathrm{~kg} \cdot \mathrm{ha}^{-1}$ as single super phosphate, and $\mathrm{K}_{2} \mathrm{O} 80 \mathrm{~kg} \cdot \mathrm{ha}^{-1}$ as potassium sulphate. Treatments were five levels of $\mathrm{SiO}_{2}$ : T1 with $\mathrm{SiO}_{2} 0 \mathrm{~kg} \cdot \mathrm{ha}{ }^{-1}$ (control), T2 with $\mathrm{SiO}_{2} 45 \mathrm{~kg} \cdot \mathrm{ha}{ }^{-1}$, T3 with $\mathrm{SiO}_{2} 90 \mathrm{~kg} \cdot \mathrm{ha}{ }^{-1}$, T4 with $\mathrm{SiO}_{2} 150 \mathrm{~kg} \cdot \mathrm{ha}^{-1}$, and $\mathrm{T} 5$ with $\mathrm{SiO}_{2} 225 \mathrm{~kg} \cdot \mathrm{ha}^{-1}$. The silicon fertilizer used, which was in the form of a sodium metasilicate $\left(\mathrm{Na}_{2} \mathrm{SiO}_{3} \cdot \mathrm{H}_{2} \mathrm{O}\right)$ with the content of soluble $\mathrm{SiO}_{2} 30 \%$, was produced by Yubei Fertilizer Company Limited, Xinxiang City, Henan Province, China. All fertilizers were applied as basal applications. In this experiment, maize was evaluated for its physiological parameters of net photosynthetic rate $\left(P_{n}\right)$, transpiration rate $(E)$, stomatal conductance $\left(g_{s}\right)$, and intercellular $\mathrm{CO}_{2}$ concentration $\left(C_{i}\right)$. Observations were recorded at four key growth stages: big trumpet stage (or the 12-leaf stage), silking stage, grain filling stage, and milk stage. The dates of growth stages are shown in Table 1.

2.3. Measurement of Gas Exchange Parameters. The photosynthetic characteristics of gas exchange parameters, $P_{n}, E$, $g_{s}$, and $C_{i}$ of the top second fully expanded leaf at the four growth stages in the field, were measured with a portable open flow gas exchange system LI-6400 (LI-COR Inc., USA) between 9:00 am and 11:00 am. The photosynthetically active radiation was $2000 \mu \mathrm{mol} \cdot \mathrm{m}^{-2} \cdot \mathrm{s}^{-1}, \mathrm{CO}_{2}$ concentration was $350 \mu \mathrm{mol} \cdot \mathrm{mol}^{-1}$, and leaf temperature was $25^{\circ} \mathrm{C}$ [13-15].

2.4. Statistical Analysis. All the data were analyzed with oneway analysis of variance (ANOVA) procedures using SPSS Version 17.0 for Windows. The differences between means were compared by Duncan's test at 0.05 significance level.
TABLE 1: Dates of growth stages of maize on saline-alkaline soil in 2012.

\begin{tabular}{lccccc}
\hline $\begin{array}{l}\text { Sowing } \\
\text { stage }\end{array}$ & $\begin{array}{c}\text { Emergence } \\
\text { stage }\end{array}$ & $\begin{array}{c}\text { Big } \\
\text { trumpet } \\
\text { stage }\end{array}$ & $\begin{array}{c}\text { Silking } \\
\text { stage }\end{array}$ & $\begin{array}{c}\text { Grain } \\
\text { filling } \\
\text { stage }\end{array}$ & $\begin{array}{c}\text { Milk } \\
\text { stage }\end{array}$ \\
\hline $4 / 26$ & $5 / 20$ & $7 / 12$ & $8 / 2$ & $8 / 16$ & $9 / 16$ \\
\hline
\end{tabular}

\section{Results}

Observed from Tables 2, 3, and 4, changes in parameters of net photosynthetic rate $\left(P_{n}\right)$, transpiration rate $(E)$, and stomatal conductance $\left(g_{s}\right)$ show that the values measured of these parameters from big trumpet stage to milk stage increased first from the beginning stage, big trumpet stage, and reached the peak values at silking stage, after which these values decreased as maize growing. According to the results of Table 5 , there is a similar changing pattern among these Si application treatments T1, T2, T3, T4, and T5, where the values of intercellular $\mathrm{CO}_{2}$ concentration $\left(C_{i}\right)$ under the five $\mathrm{Si}$ treatments continued decreasing from big trumpet stage, got the lowest values of $C_{i}$ at grain filling stage, and then slowly increased at milk stage.

3.1. Net Photosynthetic Rate $\left(P_{n}\right)$. Results showed that the parameter photosynthetic rate $\left(P_{n}\right)$ in leaves of maize was affected significantly by $\mathrm{Si}$ application treatments and $P_{n}$ was significantly decreased in later growth stages (Table 2). From big trumpet stage to milk stage, the values of $P_{n}$ under the treatments of T3, T4, and T5 $\left(90 \mathrm{~kg} \cdot \mathrm{ha}^{-1} \mathrm{Si}\right.$, $150 \mathrm{~kg} \cdot \mathrm{ha}^{-1} \mathrm{Si}$, and $225 \mathrm{~kg} \cdot \mathrm{ha}^{-1} \mathrm{Si}$ ) in the same growth stage were significantly $(P \leq 0.05)$ higher than those under the treatment of T1 and T2 $\left(0 \mathrm{~kg} \cdot \mathrm{ha}^{-1}\right.$ and $\left.45 \mathrm{~kg} \cdot \mathrm{ha}{ }^{-1} \mathrm{Si}\right)$. When the content of $\mathrm{Si}$ application reached $90 \mathrm{~kg} \cdot \mathrm{ha}^{-1} \mathrm{Si}$, the value of $P_{n}$ increased significantly $(P \leq 0.05)$ with the increased dose of Si application. Low level of Si application (T2, $45 \mathrm{~kg} \cdot \mathrm{ha}^{-1} \mathrm{Si}$ ) did not change $P_{n}$ significantly and high levels of Si application (T4, $150 \mathrm{~kg} \cdot \mathrm{ha}^{-1} \mathrm{Si}$, and T5, $225 \mathrm{~kg} \cdot \mathrm{ha}^{-1}$ Si) increased $P_{n}$ significantly $(P \leq 0.05)$, but there were no significant differences between the treatments of $150 \mathrm{~kg} \cdot \mathrm{ha}^{-1}$ Si and $225 \mathrm{~kg} \cdot \mathrm{ha}^{-1} \mathrm{Si}$ dose.

3.2. Transpiration Rate (E). During each stage from big trumpet stage to milk stage, transpiration rate $(E)$ (Table 3 ) got higher values under the treatments of $\mathrm{T} 1$ (without $\mathrm{Si}$ application) and $\mathrm{T} 2\left(45 \mathrm{~kg} \cdot \mathrm{ha}^{-1} \mathrm{Si}\right)$ than those under the treatments of T3, T4, and T5. There were no significant differences between $\mathrm{T} 1$ and $\mathrm{T} 2$. The values of $E$ significantly $(P \leq 0.05)$ decreased with the increase of Si applying dose from $90 \mathrm{~kg} \cdot \mathrm{ha}^{-1} \mathrm{Si}$ in each growth stage. Comparing the values of $E$ by $\mathrm{Si}$ application of T3, T4, and T5 with those by T1, it is shown that, during big trumpet stage, the former decreased $16.28 \%, 20.32 \%$, and $20.79 \%$, respectively, compared to those of the latter; during silking stage, the former decreased $9.44 \%, 15.63 \%$, and $16.75 \%$, respectively, compared to those of the latter; during grain filling stage, the former decreased $11.38 \%, 21.12 \%$, and $22.89 \%$, respectively, 
TABLE 2: Effects of Si application on net photosynthetic rate $\left(P_{n}\right)$ in leaves of maize.

\begin{tabular}{lcccrc}
\hline \multirow{2}{*}{ Growth stages } & & \multicolumn{3}{c}{ Photosynthetic rate $\left(P_{n}\right)\left(\mu \mathrm{mol} \cdot \mathrm{m}^{-2} \cdot \mathrm{s}^{-1}\right)$} & T4 \\
\hline Big trumpet stage & $19.15 \pm 0.25^{\mathrm{c}}$ & $18.86 \pm 0.69^{\mathrm{c}}$ & $23.02 \pm 0.73^{\mathrm{b}}$ & $24.83 \pm 0.75^{\mathrm{a}}$ & $24.95 \pm 0.42^{\mathrm{a}}$ \\
Silking stage & $33.62 \pm 0.86^{\mathrm{c}}$ & $34.11 \pm 0.62^{\mathrm{c}}$ & $37.86 \pm 0.75^{\mathrm{b}}$ & $39.30 \pm 0.55^{\mathrm{a}}$ & $39.52 \pm 0.39^{\mathrm{a}}$ \\
Grain filling stage & $24.11 \pm 0.33^{\mathrm{c}}$ & $23.93 \pm 0.50^{\mathrm{c}}$ & $26.10 \pm 0.28^{\mathrm{b}}$ & $28.35 \pm 0.37^{\mathrm{a}}$ & $28.67 \pm 0.47^{\mathrm{a}}$ \\
Milk stage & $12.70 \pm 0.59^{\mathrm{c}}$ & $12.91 \pm 0.36^{\mathrm{c}}$ & $14.32 \pm 0.53^{\mathrm{b}}$ & $16.85 \pm 0.40^{\mathrm{a}}$ & $16.89 \pm 0.33^{\mathrm{a}}$ \\
\hline
\end{tabular}

Means $( \pm \mathrm{SD})$ labeled with different letters within each column are significantly different $(P<0.05)$ by Duncan's test, $n=10$.

TABLE 3: Effects of Si application on transpiration rate $(E)$ in leaves of maize.

\begin{tabular}{|c|c|c|c|c|c|}
\hline \multirow{2}{*}{ Growth stages } & \multicolumn{5}{|c|}{ Transpiration rate $(E)\left(\mathrm{mmol} \cdot \mathrm{m}^{-2} \cdot \mathrm{s}^{-1}\right)$} \\
\hline & $\mathrm{T} 1$ & $\mathrm{~T} 2$ & T3 & $\mathrm{T} 4$ & T5 \\
\hline Big trumpet stage & $8.66 \pm 0.21^{\mathrm{a}}$ & $8.23 \pm 0.16^{\mathrm{a}}$ & $7.25 \pm 0.10^{\mathrm{b}}$ & $6.90 \pm 0.12^{\mathrm{c}}$ & $6.86 \pm 0.09^{c}$ \\
\hline Silking stage & $9.85 \pm 0.08^{\mathrm{a}}$ & $9.67 \pm 0.18^{\mathrm{a}}$ & $8.92 \pm 0.15^{\mathrm{b}}$ & $8.31 \pm 0.13^{\mathrm{c}}$ & $8.20 \pm 0.16^{\mathrm{c}}$ \\
\hline Grain filling stage & $7.82 \pm 0.15^{\mathrm{a}}$ & $7.97 \pm 0.11^{\mathrm{a}}$ & $6.93 \pm 0.13^{\mathrm{b}}$ & $6.09 \pm 0.12^{\mathrm{c}}$ & $6.03 \pm 0.09^{c}$ \\
\hline Milk stage & $4.31 \pm 0.08^{\mathrm{a}}$ & $4.15 \pm 0.10^{\mathrm{a}}$ & $3.52 \pm 0.07^{\mathrm{b}}$ & $3.03 \pm 0.08^{c}$ & $2.96 \pm 0.05^{\mathrm{c}}$ \\
\hline
\end{tabular}

Means $( \pm \mathrm{SD})$ labeled with different letters within each column are significantly different $(P<0.05)$ by Duncan's test, $n=10$.

TABLE 4: Effects of silicon on stomatal conductance $\left(g_{s}\right)$ in leaves of maize.

\begin{tabular}{|c|c|c|c|c|c|}
\hline \multirow{2}{*}{ Growth stages } & \multicolumn{5}{|c|}{ Stomatal conductance $\left(g_{s}\right)\left(\mathrm{mol} \cdot \mathrm{m}^{-2} \cdot \mathrm{s}^{-1}\right)$} \\
\hline & $\mathrm{T} 1$ & $\mathrm{~T} 2$ & T3 & $\mathrm{T} 4$ & T5 \\
\hline Big trumpet stage & $0.39 \pm 0.06^{\mathrm{b}}$ & $0.37 \pm 0.08^{b}$ & $0.40 \pm 0.02^{\mathrm{b}}$ & $0.57 \pm 0.09^{\mathrm{a}}$ & $0.56 \pm 0.07^{\mathrm{a}}$ \\
\hline Silking stage & $0.66 \pm 0.03^{\mathrm{b}}$ & $0.63 \pm 0.05^{\mathrm{b}}$ & $0.65 \pm 0.06^{\mathrm{b}}$ & $0.75 \pm 0.08^{\mathrm{a}}$ & $0.78 \pm 0.09^{\mathrm{a}}$ \\
\hline Grain filling stage & $0.47 \pm 0.08^{c}$ & $0.45 \pm 0.03^{c}$ & $0.58 \pm 0.07^{\mathrm{b}}$ & $0.66 \pm 0.05^{\mathrm{a}}$ & $0.69 \pm 0.06^{\mathrm{a}}$ \\
\hline Milk stage & $0.23 \pm 0.02^{c}$ & $0.25 \pm 0.03^{c}$ & $0.32 \pm 0.02^{\mathrm{b}}$ & $0.39 \pm 0.03^{\mathrm{a}}$ & $0.38 \pm 0.01^{\mathrm{a}}$ \\
\hline
\end{tabular}

Means $( \pm \mathrm{SD})$ labeled with different letters within each column are significantly different $(P<0.05)$ by Duncan's test, $n=10$.

TABLE 5: Effects of silicon on intercellular $\mathrm{CO}_{2}$ concentration $\left(C_{i}\right)$ in leaves of maize.

\begin{tabular}{|c|c|c|c|c|c|}
\hline \multirow{2}{*}{ Growth stages } & \multicolumn{5}{|c|}{ Intercellular $\mathrm{CO}_{2}$ concentration $\left(C_{i}\right)\left(\mu \mathrm{mol} \cdot \mathrm{mol}^{-1}\right)$} \\
\hline & $\mathrm{T} 1$ & $\mathrm{~T} 2$ & $\mathrm{~T} 3$ & $\mathrm{~T} 4$ & $\mathrm{~T} 5$ \\
\hline Big trumpet stage & $139.10 \pm 1.73^{\mathrm{d}}$ & $138.23 \pm 2.02^{\mathrm{d}}$ & $157.32 \pm 1.35^{\mathrm{c}}$ & $162.95 \pm 2.13^{\mathrm{b}}$ & $175.68 \pm 2.23^{\mathrm{a}}$ \\
\hline Silking stage & $116.82 \pm 1.69^{\mathrm{d}}$ & $120.36 \pm 1.86^{\mathrm{d}}$ & $136.20 \pm 1.57^{\mathrm{c}}$ & $140.85 \pm 1.86^{\mathrm{b}}$ & $152.61 \pm 1.75^{\mathrm{a}}$ \\
\hline Grain filling stage & $103.73 \pm 1.93^{\mathrm{d}}$ & $108.92 \pm 1.70^{\mathrm{d}}$ & $118.36 \pm 2.33^{\mathrm{c}}$ & $131.25 \pm 1.78^{\mathrm{b}}$ & $140.62 \pm 1.66^{\mathrm{a}}$ \\
\hline Milk stage & $106.90 \pm 1.28^{\mathrm{d}}$ & $112.78 \pm 1.66^{\mathrm{d}}$ & $121.32 \pm 1.51^{\mathrm{c}}$ & $134.25 \pm 1.36^{\mathrm{b}}$ & $142.83 \pm 1.92^{\mathrm{a}}$ \\
\hline
\end{tabular}

Means ( \pm SD) labeled with different letters within each column are significantly different $(P<0.05)$ by Duncan’s test, $n=10$.

compared to those of the latter; during milk stage, the former decreased $18.33 \%, 29.70 \%$, and $31.32 \%$, compared to those of the latter. There were no significant differences between the treatments of T1 and T2. So during the four studied stages, the value of $E$ of maize began to decreased significantly $(P<0.05)$ when the dose of $\mathrm{Si}$ application got to the amount of $90 \mathrm{~kg} \cdot \mathrm{ha}^{-1}$, after which the values of $E$ decreased dramatically with the increased dose of $\mathrm{Si}$ application; there was no significant difference between the treatments of doses $150 \mathrm{~kg} \cdot \mathrm{ha}^{-1}$ and $225 \mathrm{~kg} \cdot \mathrm{ha}^{-1}$.

3.3. Stomatal Conductance $\left(g_{s}\right)$. According to the data (Table 4) of big trumpet stage and silking stage, it is shown that the values of stomatal conductance $\left(g_{s}\right)$ of maize were increased significantly $(P \leq 0.05)$ at higher Si levels of T4 and T5 (150 kg.ha ${ }^{-1}$ and $\left.225 \mathrm{~kg} \cdot \mathrm{ha}^{-1}\right)$ as compared to lower levels of Si application of T1, T2, and T3 $\left(0 \mathrm{~kg} \cdot \mathrm{ha}^{-1}, 45 \mathrm{~kg} \cdot \mathrm{ha}^{-1}\right.$, and $\left.90 \mathrm{~kg} \cdot \mathrm{ha}^{-1}\right)$. There were no significant differences between the treatments of T4 and T5 as well as among the treatments of $\mathrm{T} 1, \mathrm{~T} 2$, and T3. The data (Table 4) showed that, at grain filling stage and milking stage, the values of $g_{s}$ of maize significantly $(P<0.05)$ increased by Si application at levels of $90 \mathrm{~kg} \cdot \mathrm{ha}^{-1}$ (T3), $150 \mathrm{~kg} \cdot \mathrm{ha}^{-1}$ (T4), and $225 \mathrm{~kg} \cdot \mathrm{ha}^{-1}$ (T5); the values of $g_{s}$ of maize were significantly enhanced with the increased dose of $\mathrm{Si}$ application of $90 \mathrm{~kg} \cdot \mathrm{ha}^{-1}$; there were significant differences between $\mathrm{T} 3$ and $\mathrm{T} 4$, and there was no significant 
difference between T4 and T5. So at big trumpet stage and silking stage, the value of $g_{s}$ of maize began to increase significantly $(P<0.05)$ when the dose of Si application got to the amount of $150 \mathrm{~kg} \cdot \mathrm{ha}^{-1}$; there was no significant difference in the values of $g_{s}$ of maize between the treatments of doses $150 \mathrm{~kg} \cdot \mathrm{ha}^{-1}$ and $225 \mathrm{~kg} \cdot \mathrm{ha}^{-1}$; at grain filling stage and milk stage, the value of $g_{s}$ of maize began to increase significantly $(P<0.05)$ when the dose of Si application got to the amount of $90 \mathrm{~kg} \cdot \mathrm{ha}^{-1}$, after which the values of $g_{s}$ of maize were enhanced significantly with the increased dose of Si application; there was no significant difference between the treatments of doses $150 \mathrm{~kg} \cdot \mathrm{ha}^{-1}$ and $225 \mathrm{~kg} \cdot \mathrm{ha}^{-1}$.

3.4. Intercellular $\mathrm{CO}_{2}$ Concentration $\left(C_{i}\right)$. From big trumpet stage to milk stage, the data (Table 5 ) showed that the values of intercellular $\mathrm{CO}_{2}$ concentration $\left(C_{i}\right)$ of maize with the $\mathrm{Si}$ treatments of T3, T4, and T5 were significantly $(P \leq 0.05)$ higher than those with $\mathrm{T} 1$ and $\mathrm{T} 2$; there was no significant difference between the treatments of $\mathrm{T} 1$ and $\mathrm{T} 2$. The values of $C_{i}$ began to increase significantly $(P \leq 0.05)$ when the dose of Si application got to the amount of $90 \mathrm{~kg} \cdot \mathrm{ha}^{-1}$, after which the values of $C_{i}$ were dramatically enhanced with the increased dose of $\mathrm{Si}$ application; there were significant $(P \leq$ 0.05 ) differences among the treatments of T3, T4, and T5. During big trumpet stage, comparing the values of $C_{i}$ by $\mathrm{Si}$ application of T3, T4, and T5 with those by T1, it is shown that the former increased $13.1 \%, 17.1 \%$, and $26.3 \%$, respectively, compared to those of the latter; during silking stage, the former increased $16.6 \%, 20.6 \%$, and $30.6 \%$, respectively, compared to those of the latter; during grain filling stage, the former increased $14.1 \%, 26.5 \%$, and $35.6 \%$, respectively, compared to those of the latter; during milk stage, the former increased $13.5 \%, 25.5 \%$, and $33.6 \%$ compared to those of the latter. There was no significant difference between the treatments of T1 and T2. So in these four studied stages, the value of $C_{i}$ of maize began to increase significantly $(P<$ $0.05)$ when the dose of Si application got to the amount of $90 \mathrm{~kg} \cdot \mathrm{ha}^{-1}$, after which the values of $C_{i}$ increased dramatically with the increase of dose of Si applying.

\section{Discussion}

Under abiotic stresses such as toxicity, salinity, and lodging, silicon is reported to improve the growth of many kinds of higher plants [16]. Silicon can improve the growth of plants under salinity stress [17]. Exogenously applied Si significantly increased photosynthetic efficiency $(A)$, stomatal conductance $\left(g_{s}\right)$ and increased internal $\mathrm{CO}_{2}$ concentration $\left(C_{i}\right)$ in maize under saline conditions $[18,19]$. Our results showed that, under the condition of saline-alkaline soil, the values of $P_{n}, C_{i}$, and $g_{s}$ of maize leaves were significantly enhanced by $\mathrm{Si}$ application and that of $E$ was decreased with the increase of Si supplied; similar improvement was reported in crops of strawberry, maize, Chinese cabbage, and rice [2023]. The main mechanisms of improving crops growth by silicon lie in its functions of stimulation of photosynthesis, reduction of plant transpiration rate, and enhancement of tissue strength [24]. Our researches showed that, in the four studied growth stages, the values of $P_{n}$ by $\mathrm{Si}$ application were significantly enhanced compared with those with no $\mathrm{Si}$ application. Similar results were reported that addition of $\mathrm{Si}$ can enhance the photochemical efficiency of plants under salt stress [25]. Photosynthetic capacities of crops treated by $\mathrm{Si}$ application can be improved because the size of chloroplasts is enlarged and the number of grana in leaves is increased [26]. Researches on crops of barely (Hordeum vulgare L.), rice (Oryza sativa L.), sugarcane (Saccharum officinarum L.), and wheat (Triticum aestivum L.) showed that silicon deposited in leaves is helpful to improve the potential and efficiency of photosynthesis by opening angle of leaves, decreasing selfshading, and keeping the leaf erect [27], which play important roles in increasing $P_{n}$ of crops.

According to our research, during the studied growth stages, the value of $E$ of maize began to decrease significantly $(P<0.05)$ at the dose of $90 \mathrm{~kg} \cdot \mathrm{ha}^{-1} \mathrm{Si}$ application, and above this dose of $\mathrm{Si}$ application the values of $E$ decreased dramatically with the increased dose of Si application. By $\mathrm{Si}$ application, plant's internal water stress can be reduced; therefore, salt stress can be withstood as the rate of transpiration being influenced by the amount of Si gel associated with the cellulose in the cell walls of epidermal cells [28]. Similar results showed that water loss in maize can by reduced by $\mathrm{Si}$ application because $\mathrm{Si}$ can change the morphological structures of leaf epidermal cell [29]. Si is deposited in leaves leading towards decreased transpiration and hence dilutes salts accumulated in saline environment [30]. Unnecessary water loss can be limited through the epidermis, which is double layer, and silica combines with cellulose in the epidermal cells of leaf blade [31]. Another reason to explain the decrease of $E$ is that the stomata opening can be influenced by Si [32]. Salt-stressed plants supplied with Si showed values of WUE $17 \%$ greater than those of salinized plants which were not supplied with Si by reducing the transpiration [30].

In our research, the value of $g_{s}$ of maize began to increase significantly when the dose of Si application got to the amount of $150 \mathrm{~kg} \cdot \mathrm{ha}^{-1}$ at big trumpet stage and silking stage; the value of $g_{s}$ of maize began to increase significantly when the dose of Si application got to the amount of $90 \mathrm{~kg} \cdot \mathrm{ha}^{-1}$, after which the values of $g_{s}$ of maize were enhanced significantly with the increased dose of Si application at grain filling stage and milk stage. Similar reports on rice (Oryza sativa L.) are that $\mathrm{Si}$ application can enhance the stomatal conductance of rice plants subjected to salt stress, which shows silicate can reduce $\mathrm{Na}$ uptake via decline in the transpiration rate [30]. Silicon added to the saline growth medium improved photosynthetic activity $[18,19]$. Si amendment enhanced the stomatal conductance of rice plants subjected to salt stress showing that silicate can reduce $\mathrm{Na}$ uptake via decline in the transpiration rate, which ultimately results into the reduction in growth and net photosynthesis [10]. It was also reported that $g_{s}$ can be increased by $\mathrm{Si}$ fertilizer, because the increased $g_{s}$ can regulate gas exchange, increase $\mathrm{CO}_{2}$ uptake, and subsequently improve the capacity and efficiency of photosynthesis [18, 19, 33-39].

In the four studied growth stages, the value of $C_{i}$ of maize began to increase significantly at the dose of $90 \mathrm{~kg} \cdot \mathrm{ha}^{-1} \mathrm{Si}$ 
application, after which the values of $C_{i}$ increased dramatically with the increase of dose of Si application, which showed that photosynthetic efficiency of leaves can be enhanced by Si application [18]. Si applying can prevent the activities of photosynthetic enzymes in mesophyll cells from decreasing [34]. Si application reduces the transpiration rate to restrict the Na uptake; as a result, $\mathrm{CO}_{2}$ intake is enhanced [10]. Under salt stress condition, the double membranes of chloroplasts disappeared, but membrane integrity was markedly improved in the salt treatment supplemented with $\mathrm{Si}$ [35]. The values of $C_{i}$ can be increased dramatically by $\mathrm{Si}$ application under salt stress, which is stressful environment with the accumulation of ROS, such as superoxide radicals $\left(\mathrm{O}_{2}{ }^{--}\right)$, hydroxyl radicals $\left(\mathrm{OH}^{-}\right)$, and hydrogen peroxide $\left(\mathrm{H}_{2} \mathrm{O}_{2}\right)$, and the activity of defense system affected by salinity stress may be enhanced by Si application [10, 19, 36-43].

\section{Conclusion}

Silicon plays an important role to enhance photosynthesis ability and efficiency of plants under salinity stress [10]. The field research showed that values of photosynthetic rate $\left(P_{n}\right)$, stomatal conductance $\left(g_{s}\right)$, transpiration rate $(E)$, and intercellular $\mathrm{CO}_{2}$ concentration $\left(C_{i}\right)$ of maize plants in salinealkaline soil were affected by $\mathrm{Si}$ application and salinity stress can be alleviated by $\mathrm{Si}$ application. In our research, the optimal dose of $\mathrm{Si}$ application on saline-alkaline soil was $150 \mathrm{~kg} \cdot \mathrm{ha}^{-1}$, under which photosynthetic ability of maize was greatly increased at studied growth stages. So in this research, increase in maize photosynthesis under saline-alkaline stress took place by $\mathrm{Si}$ application with proper doses, with which it is helpful to improve growth and yield of cereal crops [29].

\section{Conflict of Interests}

The authors declare that there is no conflict of interests regarding the publication of this paper.

\section{Acknowledgments}

This research was supported by the National Natural Science Foundation of China $(31271672 ; 41301314 ; 41201559)$, the National Science and Technology Support Program of China (2012BAD42B01), the Natural Science Foundation of Jiangsu Province (BK2011412), and the CAS/SAFEA International Partnership Program for Creative Research Teams.

\section{References}

[1] Y. Liang, Q. Chen, Q. Liu, W. Zhang, and R. Ding, "Exogenous silicon $(\mathrm{Si})$ increases antioxidant enzyme activity and reduces lipid peroxidation in roots of salt-stressed barley (Hordeum vulgare L.)," Journal of Plant Physiology, vol. 160, no. 10, pp. 11571164, 2003.

[2] C. N. Deng, G. X. Zhang, X. L. Pan, and K. Y. Zhao, "Chlorophyll fluorescence and gas exchange responses of maize seedlings to saline-alkaline stress," Bulgarian Journal of Agricultural Science, vol. 16, no. 1, pp. 49-58, 2010.
[3] T. A. Ishida, K. Nara, S. Ma, T. Takano, and S. Liu, "Ectomycorrhizal fungal community in alkaline-saline soil in northeastern China," Mycorrhiza, vol. 19, no. 5, pp. 329-335, 2009.

[4] I. Afzal, S. M. A. Basra, T. E. Lodhi, and S. J. Butt, "Improving germination and seedling vigour in wheat by halopriming under saline conditions," Pakistan Journal of Agricultural Sciences, vol. 44, no. 1, pp. 40-49, 2007.

[5] R. Anjum, A. Ahmed, R. Ullah, M. Jahangir, and M. Yousaf, "Effect of soil salinity/sodicity on the growth and yield of different varieties of cotton," International Journal of Agriculture and Biology, vol. 7, no. 4, pp. 606-608, 2005.

[6] Z. Khodarahmpour, M. Ifar, and M. Motamedi, "Effects of $\mathrm{NaCl}$ salinity on maize (Zea mays L.) at germination and early seedling stage," African Journal of Biotechnology, vol. 11, no. 2, pp. 298-304, 2012.

[7] A. L. Tuna, C. Kaya, D. Higgs, B. Murillo-Amador, S. Aydemir, and A. R. Girgin, "Silicon improves salinity tolerance in wheat plants," Environmental and Experimental Botany, vol. 62, no. 1, pp. 10-16, 2008.

[8] J. F. Ma and N. Yamaji, "Silicon uptake and accumulation in higher plants," Trends in Plant Science, vol. 11, no. 8, pp. 392397, 2006.

[9] A. C. Marafon and L. Endres, "Silicon: fertilization and nutrition in higher plants," Amazonian Journal of Agricultural and Environmental Sciences, vol. 56, no. 4, pp. 380-388, 2013.

[10] A. Ali, S. M. A. Basra, S. Hussain, J. Iqbal, M. A. A. H. A. Bukhsh, and M. Sarwar, "Salt stress alleviation in field crops through nutritional supplementation of silicon," Pakistan Journal of Nutrition, vol. 11, no. 8, pp. 735-735, 2012.

[11] Y. Liang, J. Si, and V. Römheld, "Silicon uptake and transport is an active process in Cucumis sativus," New Phytologist, vol. 167, no. 3, pp. 797-804, 2005.

[12] S. Cha-Um and C. Kirdmanee, "Effect of salt stress on proline accumulation, photosynthetic ability and growth characters in two maize cultivars," Pakistan Journal of Botany, vol. 41, no. 1, pp. 87-98, 2009.

[13] S. Covshoff and J. M. Hibberd, "Integrating $\mathrm{C}_{4}$ photosynthesis into $\mathrm{C}_{3}$ crops to increase yield potential," Current Opinion in Biotechnology, vol. 23, no. 2, pp. 209-214, 2012.

[14] S. Q. Zhang, Plant Physiology Experimental Techniques Tutorial, Science Press, Beijing, China, 2011, (Chinese).

[15] H.-W. Xu, F.-B. Song, X.-C. Zhu, and S.-Y. Tong, "Photosynthesis, chlorophyll fluorescence and nonstructural carbohydrates changes in husk leaves of maize in black soils region of Northeast China," African Journal of Agricultural Research, vol. 5, no. 9, pp. 785-791, 2010.

[16] E. Epstein, "Silicon," Annual Review of Plant Biology, vol. 50, pp. 641-664, 1999.

[17] Y. Liang, Q. Shen, Z. Shen, and T. Ma, "Effects of silicon on salinity tolerance of two barley cultivars," Journal of Plant Nutrition, vol. 19, no. 1, pp. 173-183, 1996.

[18] N. Parveen and M. Ashraf, "Role of silicon in mitigating the adverse effects of salt stress on growth and photosynthetic attributes of two maize (Zea mays L.) cultivars grown hydroponically," Pakistan Journal of Botany, vol. 42, no. 3, pp. 1675-1684, 2010.

[19] K. Yan, P. Chen, H. Shao, C. Shao, S. Zhao, and M. Brestic, "Dissection of photosynthetic electron transport process in sweet sorghum under heat stress ," PLoS ONE, vol. 8, no. 5, Article ID e62100, 2013. 
[20] C. Gao, J. B. Liu, H. B. Chang, X. B. Yu, and H. S. Xu, "Effects of silicon on rice leaf photosynthesis and ultrastructure," Journal of Jilin Agricultural University, vol. 33, no. 1, pp. 3049-3057, 2011 (Chinese).

[21] X. D. Yang, Effect of N Si fertilizer on the growth and yield of Chinese cabbage [M.S. thesis], Shandong Agricultural University, 2010 (Chinese).

[22] L. Z. Shu and H. Y. Liu, "Effects of silicon on growth of maize seedlings under salt stress," Agro-Environmental Protection, vol. 20, no. 1, pp. 38-40, 2001.

[23] J. Y. Wang, M. D. Liu, and D. Li, "Effects of silicon enrichment on photosynthetic characteristics and yield of strawberry," Northern Horticulture, no. 12, pp. 90-92, 2009 (Chinese).

[24] J. F. Ma and E. Takahashi, Soil, Fertilizer, and Plant Silicon Research in Japan, Elsevier Science, Amsterdam, The Netherlands, 2002.

[25] A. Ali, S. M. A. Basra, J. Iqbal et al., "Silicon mediated biochemical changes in wheat under salinized and non-salinzed solution cultures," African Journal of Biotechnology, vol. 11, no. 3, pp. 606615, 2012.

[26] X. D. Yang, Effect of N Si fertilizer on the growth and yield of Chinese cabbage [M.S. thesis], Shandong Agricultural University, 2010, (Chinese).

[27] R. P. Soratto, C. A. C. Crusciol, G. S. A. Castro, C. H. M. da Costa, and J. F. Neto, "Leaf application of silicic acid to white oat and wheat," Revista Brasileira de Ciencia do Solo, vol. 36, no. 5, pp. 1538-1544, 2012.

[28] T. Aziz, M. A. Gill, and R. Rahmathllah, "Silicon nutrition and crop production: a review," Pakistan Journal of Agricultural Sciences, vol. 39, no. 3, pp. 181-187, 2002.

[29] J. Ren, J. R. Guo, X. Q. Xing, G. Qi, and Z. L. Yuan, "Preliminary exploration into yield increase effects and yield increase mechanism of silicate fertilizer on maize," Journal of Maize Sciences, vol. 10, no. 2, pp. 84-86, 2002 (Chinese).

[30] A. Ali, S. M. A. Basra, S. Hussain, J. Iqbal, M. A. A. H. A. Bukhsh, and M. Sarwar, "Salt stress alleviation in field crops through nutritional supplementation of silicon," Pakistan Journal of Nutrition, vol. 11, no. 8, pp. 637-655, 2012.

[31] J. Lewin and B. E. F. Reimann, "Silicon and plant growth," Annual Review of Plant Physiology, vol. 20, pp. 289-304, 1969.

[32] S. Agarie, H. Uchida, W. Agata, F. Kubota, and P. B. Kaufman, "Effects of silicon on transpiration and leaf conductance in rice plants (Oryza saliva L.)," Plant Production Science, vol. 1, no. 2, pp. 89-95, 1998.

[33] K. Kusumi, S. Hirotsuka, T. Kumamaru, and K. Iba, "Increased leaf photosynthesis caused by elevated stomatal conductance in a rice mutant deficient in SLAC1, a guard cell anion channel protein," Journal of Experimental Botany, vol. 63, no. 15, pp. 5635-5644, 2012.

[34] B. L. Cao, K. Xu, J. Shi, G. F. Xin, C. Y. Liu, and X. Li, "Effects of silicon on growth, photosynthesis and transpiration of tomato," Plant Nutrition and Fertilizer Science, vol. 19, no. 2, pp. 354-360, 2013 (Chinese).

[35] L. Yongchao, "Effect of silicon on leaf ultrastructure, chlorophyll content and photosynthetic activity of barley under salt stress," Pedosphere, vol. 8, no. 4, pp. 289-296, 1998.

[36] Y. P. Song, Effects of exogenous Si on growth and physiological characteristics of cucumber seedlings under $\mathrm{NO}_{3}^{-}$stress [M.S. thesis], Shandong Agricultural University, 2011, (Chinese).

[37] W. Song, A. Zheng, H. Shao, L. Chu, M. Brestic, and Z. Zhang, "The alleviative effect of salicylic acid on the physiological indices of the seedling leaves in six different wheat genotypes under lead stress," Plant OMICS, vol. 5, no. 5, pp. 486-493, 2012.

[38] M. Brestic, M. Zivcak, H. M. Kalaji, R. Carpentier, and S. I. Allakhverdiev, "Photosystem II thermostability in situ: environmentally induced acclimation and genotype-specific reactions in Triticum aestivum L," Plant Physiology and Biochemistry, vol. 57, pp. 93-105, 2012.

[39] W. Tan, Q. W. Meng, M. Brestic, K. Olsovska, and X. Yang, "Photosynthesis is improved by exogenous calcium in heatstressed tobacco plants," Journal of Plant Physiology, vol. 168, no. 17, pp. 2063-2071, 2011.

[40] S. Hong-Bo, L. Zeng-Hui, Z. Zheng-Bin, C. Qi-Jie, C. Li-Ye, and M. Brestic, "Biological roles of crop NADP-malic enzymes and molecular mechanisms involved in abiotic stress," African Journal of Biotechnology, vol. 10, no. 25, pp. 4947-4953, 2011.

[41] M. Zivcak, H. M. Kalaji, H.-B. Shao, K. Olsovska, and M. Brestic, "Photosynthetic proton and electron transport in wheat leaves under prolonged moderate drought stress," Journal of Photochemistry and Photobiology B: Biology, vol. 137, pp. 107-115, 2014.

[42] H. M. Kalaji, K. Bosa, J. Kościelniak, and K. Żuk-Gołaszewska, "Effects of salt stress on photosystem II efficiency and $\mathrm{CO}_{2}$ assimilation of two Syrian barley landraces," Environmental and Experimental Botany, vol. 73, no. 1, pp. 64-72, 2011.

[43] J. Kościelniak, A. Ostrowska, J. Biesaga-Kościelniak et al., “The effect of zearalenone on PSII photochemical activity and growth in wheat and soybean under salt $(\mathrm{NaCl})$ stress," Acta Physiologiae Plantarum, vol. 33, no. 6, pp. 2329-2338, 2011. 

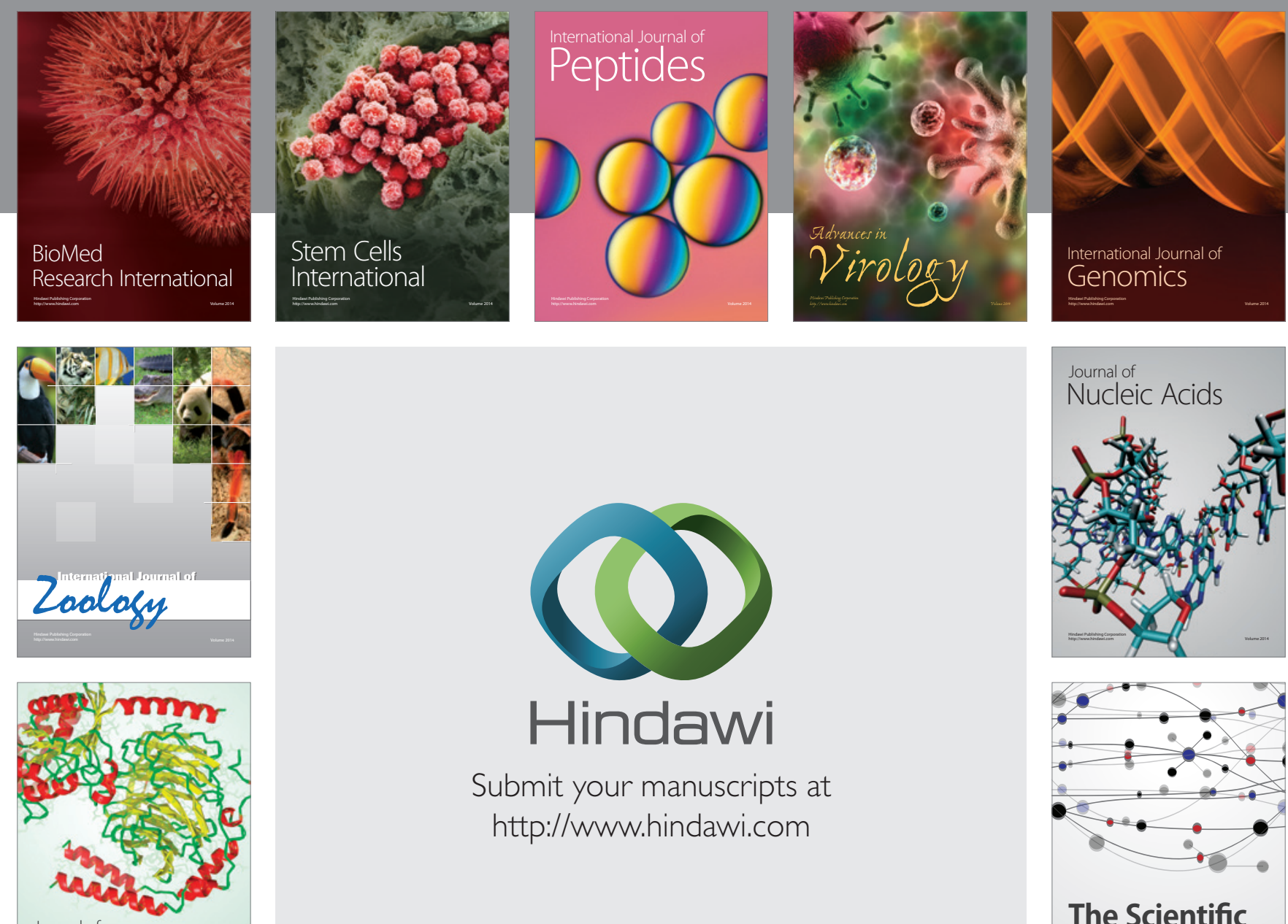

Submit your manuscripts at

http://www.hindawi.com

Journal of
Signal Transduction
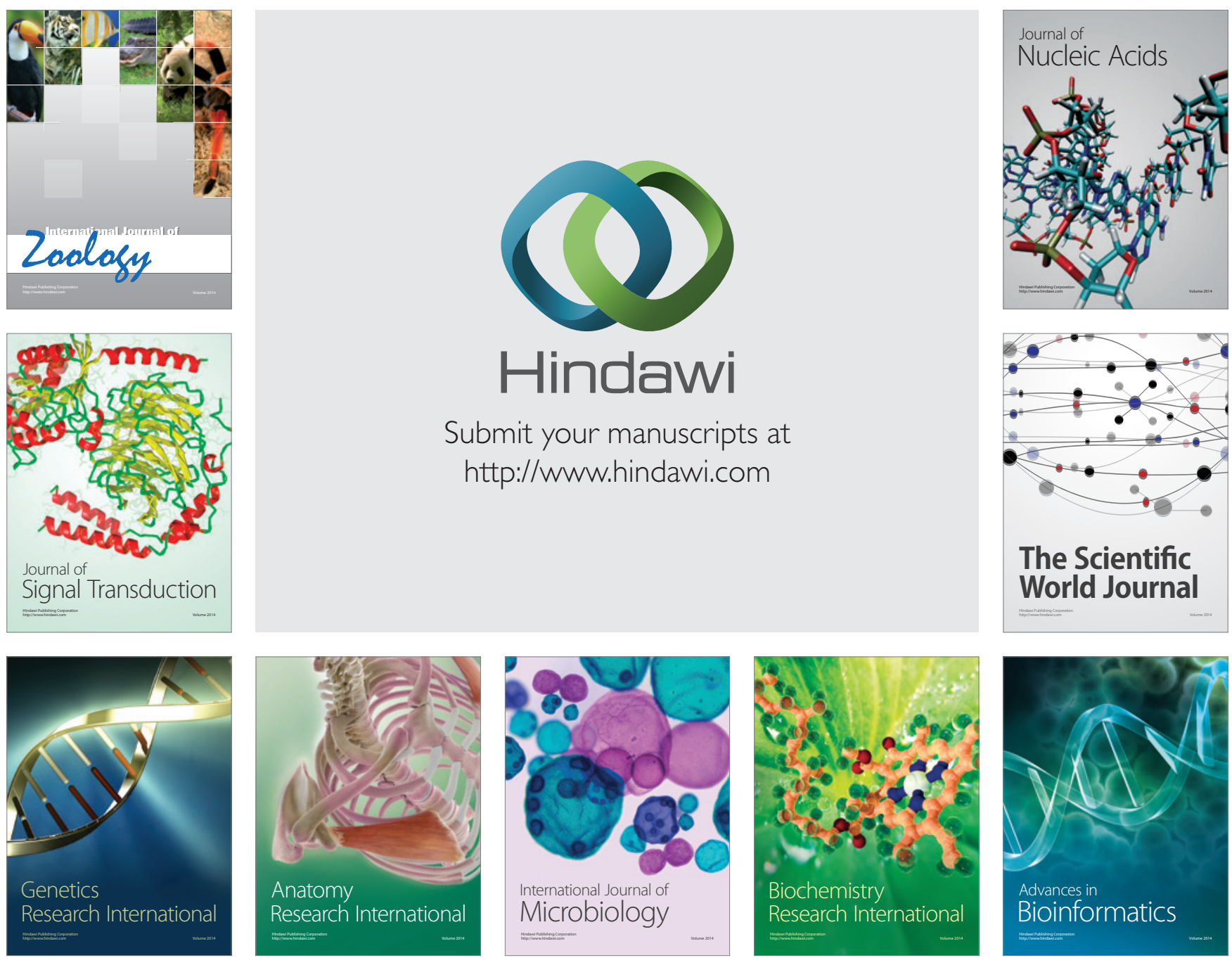

The Scientific World Journal
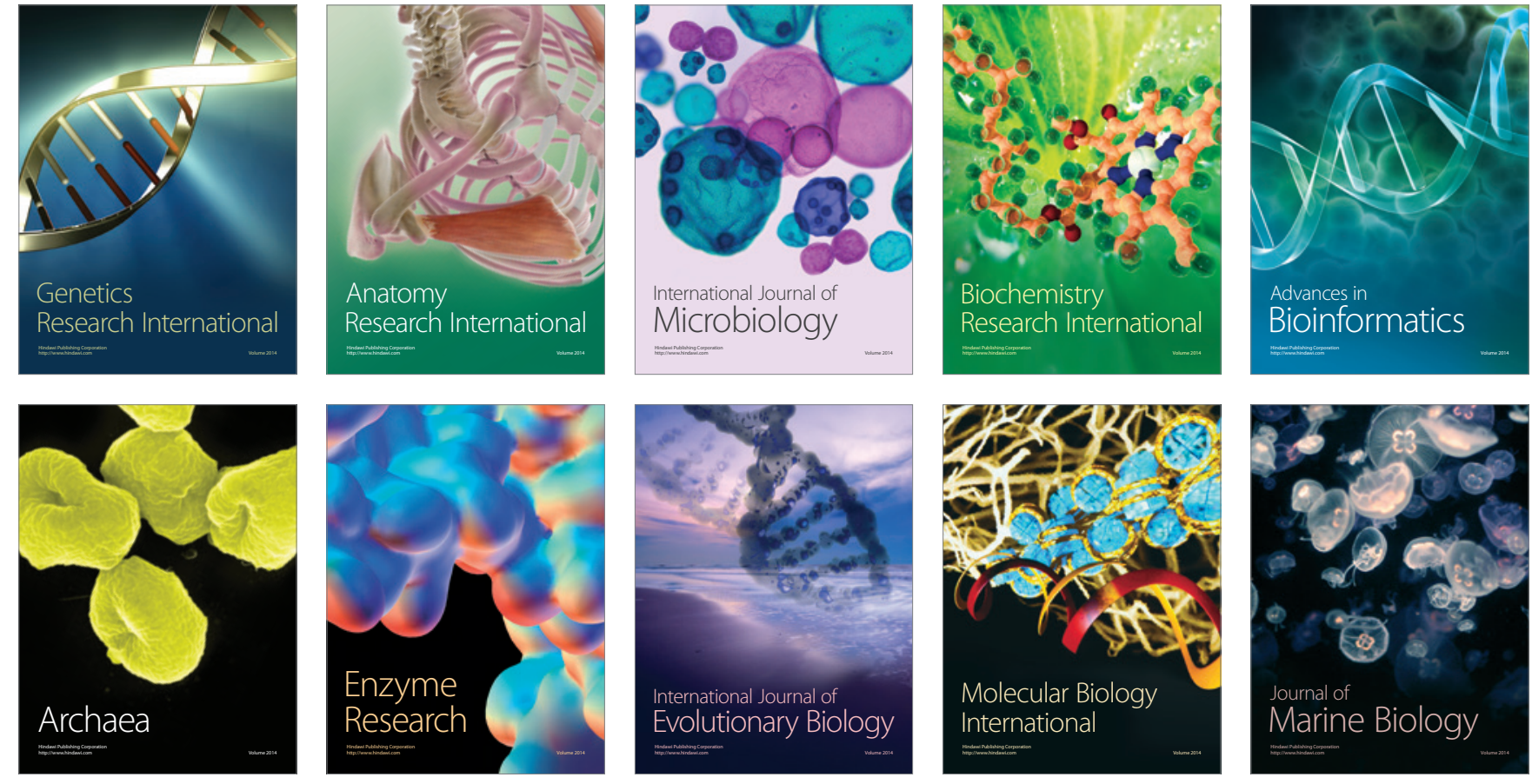